DOI: https://doi.org/10.47405/mjssh.v5i9.495

\begin{tabular}{|c|c|}
\hline 1. 1.54 & Malaysian Journal of Social Sciences and Humanities (MJSSH) \\
\hline $\begin{array}{c}\text { Malaysian Journal of } \\
\text { solal sciences and }\end{array}$ & Volume 5, Issue 9, September 2020 \\
\hline (MJ-SSH) & e-ISSN : 2504-8562 \\
\hline & $\begin{array}{l}\text { Journal home page: } \\
\text { www.msocialsciences.com }\end{array}$ \\
\hline
\end{tabular}

\title{
Faktor-faktor yang Mempengaruhi Pemilihan Mod Pengangkutan dalam kalangan Warga Asing di Kota Kinabalu, Sabah
}

\author{
Roshimah Zakaria ${ }^{1}$, Harifah Mohd Noor ${ }^{1}$ \\ ${ }^{1}$ Fakulti Sains Sosial dan Kemanusiaan, Universiti Malaysia Sabah (UMS) \\ Correspondence: Roshimah Zakaria (roshimahz@yahoo.com)
}

\begin{abstract}
Abstrak
Perkembangan pengangkutan di Malaysia khususnya Kota Kinabalu semakin berkembang dari semasa ke semasa. Namun pertambahan bilangan warga asing turut mempengaruhi infrastruktur pengangkutan. Perkara ini menunjukkan bahawa warga asing telah menyumbang kepada peningkatan perjalanan menggunakan pelbagai mod pengangkutan dan pertumbuhan penggunaan pengangkutan awam. Oleh itu, kajian ini akan mengenal pasti faktor yang mempengaruhi penggunaan mod pengangkutan warga asing yang melibatkan pengedaran borang soal selidik kepada 150 responden menerusi kaedah persampelan bertujuan dan snowball. Data kajian dianalisis menggunakan statistik deskriptif yang menghasilkan taburan frekuensi dan peratusan serta ujian Khi-Square menggunakan alat analisis Statistical Packages for the Social Sciences (SPSS) yang melibatkan enam faktor sosioekonomi iaitu umur, jantina, status pekerjaan, pendapatan, taraf perkahwinan dan pemilikan kenderaan. Hasil kajian menunjukkan terdapat empat pembolehubah yang signifikan terhadap penggunaan mod pengangkutan iaitu jantina, status pekerjaan, pendapatan dan pemilikan kenderaan. Mod pengangkutan utama respoden adalah berjalan kaki dan penggunaan pengangkutan awam. Responden yang mempunyai pendapatan yang stabil dan pekerjaan yang tetap serta berkeluarga pula cenderung untuk menggunakan kenderaan persendirian. Pembolehubah faktor sosioekonomi ini boleh dijadikan panduan kepada Pihak Berkuasa Tempatan (PBT) dan pihak berkepentingan seperti agensi pengangkutan dalam merancang strategi sasaran penggunaan pengangkutan awam yang lebih menyeluruh pada masa akan datang khususnya di Kota Kinabalu.
\end{abstract}

Kata kunci: warga asing, faktor sosioekonomi, mod pengangkutan, pengangkutan awam

\section{Factors Influencing Travel Mode Choice Among Immigrants in Kota Kinabalu, Sabah}

\begin{abstract}
The development of transportation in Malaysia, especially Kota Kinabalu, is growing from time to time. However, the increase in the number of immigrants also affects the transport infrastructure. This indicates that immigrants have contributed to the increase in travel using various modes of transport and the growth of public transport use. Therefore, this study will identify the factors that influence the use of immigrants transport mode involving the distribution of questionnaires to 150 respondents through the purposive and snowball sampling. Study data were analyzed using descriptive statistics that produced frequency and percentage distributions and Khi-Square tests using Statistical Packages for the Social Sciences (SPSS) analysis tool which involved six socio-economic factors namely age, gender, employment status, income, marital status and vehicle ownership. The results show that there
\end{abstract}


are four significant variables on the use of transportation modes, namely gender, employment status, income and vehicle ownership. The main modes of transport of respondents are walking and the use of public transport. Respondents with stable incomes and regular jobs as well as families tend to use private vehicles. These socio-economic factor variables can be used as a guide for Local Authorities (PBT) and stakeholders such as transport agencies in planning a more comprehensive strategy for the use of public transport in the future, especially in Kota Kinabalu.

Keywords: immigrants, socioeconomic factors, modes of transportation, public transport

\section{Pengenalan}

Malaysia sebagai sebuah negara sedang membangun menyaksikan bahawa negara semakin berkembang maju dari semasa ke semasa seiring dengan negara maju yang lain. Kemajuan negara ini secara tidak langsung telah memberi impak kepada sektor pengangkutan. Pengangkutan merupakan salah satu elemen infrastruktur yang boleh mempercepat dan menggalakkan pertumbuhan ekonomi di sesebuah kawasan. Hal ini demikian kerana menurut Katiman (2002) pengangkutan diperlukan kerana motif atau kepentingan ekonomi dan sosial (Shamsudin \& Wan Rozali, 2015). Namun begitu, peningkatan kenderaan bermotor saban hari menyebabkan ia menjadi salah satu agenda yang penting untuk negara bagi mencapai pengangkutan yang mapan.

Menurut Harifah et al. (2015) penggunaan pengangkutan awam bukan lagi simbol status terhadap ekonomi, tapi simbol kejayaan sesebuah negara menjaga kualiti kehidupan penduduknya. Pengukuran kualiti hidup seseorang individu berkait rapat dengan aksesibiliti terhadap pekerjaan, peluang pendidikan, perkhidmatan awam yang efisien dan kemudahan rekreasi disediakan dalam kawasan tempat tinggal penduduk (Abreha, 2007; Saravanan et al., 2019). Perkhidmatan pengangkutan awam adalah salah satu perkhidmatan bandar yang penting untuk penduduk bandar. Penggunaan pengangkutan awam sering dikaitkan dengan faktor sosioekonomi penduduk seperti umur, pendapatan, jantina, pemilikan kenderaan dan status pekerjaan.

Namun begitu, pengangkutan awam ini bukan sahaja digunakan oleh penduduk tempatan tetapi juga penduduk asing yang berhijrah ke Malaysia. Kebanjiran warga asing di Malaysia termasuklah bandarbandar di Sabah bukanlah suatu perkara yang baru. Statistik pekerja asing di Sabah mencecah sebanyak 126533 orang tidak termasuk pendatang asing tanpa izin dalam laporan Kementerian Dalam Negeri (2018). Kehadiran pendatang asing ini sedikit sebanyak merupakan golongan yang membantu dalam sektor pembinaan, perkhidmatan dan pekerja pembersihan (Mustafa, 2014). Oleh itu, untuk meneruskan kelangsungan hidup golongan ini akan melakukan pergerakan dari sayi tempat ke satu tempat yang lain. Perkara ini secara tidak langsung telah memberi pengaruh dan kesan terhadap sektor pengangkutan. Hal ini disokong oleh Sungyop Kim (2009) yang menyatakan bahawa mobiliti pengangkutan adalah salah satu komponen yang paling penting untuk memudahkan aktiviti ekonomi imigran baru.

Oleh itu, kertas kerja ini adalah untuk mengenal pasti pengaruh faktor sosioekonomi terhadap penggunaan mod pengangkutan dalam kalangan warga asing di Kota Kinabalu bagi mengetahui potensi penggunaanya pada masa akan datang. Terdapat enam faktor sosioekonomi yang mempengaruhi penggunaan mod pengangkutan yang akan dibincangkan dalam kertas kerja ini iaitu umur, jantina, pendapatan, taraf perkahwinan, status pekerjaan dan pemilikan kenderaan sepertimana dinyatakan dalam Hensher (1987) dan Harifah et al. (2015).

\section{Tinjauan Literatur}

Pengaruh sosioekonomi terhadap penggunaan mod pengangkutan 
Pilihan penggunaan mod pengangkutan dipengaruhi oleh pelbagai faktor. Faktor penggunaan mod pengangkutan boleh dibahagikan kepada dua iaitu faktor dalaman dan luaran (Taylor \& Fink, 2003; Carr, 1986). Faktor dalaman merujuk kepada dasar dan agensi yang bertanggungjawab terhadap kualiti perkhidmatan pengangkutan awam, manakala faktor luaran termasuk harga bahan bakar, penggunaan tanah dan pertumbuhan pembangunan. Faktor-faktor sosioekonomi seperti umur, pendapatan, status pekerjaan dan jantina, yang memainkan peranan penting dalam menentukan kadar penggunaan pengangkutan awam (Taylor \& Breiland, 2007). Kajian lepas juga menunjukkan umur, jantina, status pekerjaan, sektor pekerjaan, pendapatan, status perkahwinan, pasangan kerja dan pemilikan kenderaan mempengaruhi penggunaan pengangkutan awam (Taylor \& Fink, 2003). Senario penggunaan mod pengangkutan di negara membangun seperti Malaysia turut dipengaruhi oleh faktor sosioekonomi. Kajian Nurdden et al. (2007) mendapati lima faktor sosioekonomi seperti umur, jantina, pemilikan kenderaan serta pendapatan yang mempengaruhi penggunaan pengangkutan awam manakala dalam kajian Harifah et al. (2015) terdapat tujuh faktor sosioekonomi iaitu umur, jantina, pendapatan, taraf perkahwinan, status pekerjaan dan pemilikan kenderaan.

Kurt (2018) menyatakan bahawa berdasarkan laporan National Household Survey (NHTS) tahun 2009 penduduk Amerika Syarikat yang berumur 16 ke 25 tahun mempunyai keberangkalian yang tinggi dalam penggunaan pengangkutan awam. Hal ini demikian kerana golongan muda ini belum berkemampuan untuk membeli kenderaan persendirian dan lebih mudah untuk bergerak menggunakan pengangkutan awam berbanding golongan yang lebih berusia yang mempunyai kewangan yang lebih stabil. Selain itu, faktor jantina juga mempengaruhi dalam pemiliihan penggunaan mod pengangkutan. Hasil daripada kajian beberapa penyelidik menyatakan bahawa kaum wanita lebih kerap menggunakan perkhidmatan pengangkutan awam kerana kebanyakan mereka kurang terdedah pada motosikal dan lesen kereta, kurang menggunakan kenderaan persendirian, serta kurang membuat perjalanan (Mazdi dan Jamilah, 2006; Abd Rahim, 2004; Balcombe et al., 2004). Namun begitu, penduduk yang berpendapatan rendah merupakan pengguna pengangkutan awam yang terbesar dalam kajian di Portland, tetapi golongan ini masih ketinggalan dari kawasan yang mempunyai perkhidmatan pengangkutan yang lebih berkualiti (Tom \& Madeline, 2017). Manakala kajian di Atlanta sekitar tahun 2000 sehingga 2009, penggunaan pengangkutan awam menurun di pusat bandar dan dalam bandar tetapi meningkat di kawasan lingkaran pinggir luar bandar walaupun pendapatan isi rumah penduduk di kawasan pinggir luar bandar (suburb) telah menurun pada tahun 2000 sehingga 2009 dan pendapatan penduduk di pusat bandar meningkat sebanyak 61 peratus (Wang \& Woo, 2017). Hasil kaijan penyelidik ini menunjukkan bahawa kebanyakan pengguna pengangkutan awam adalah daripada golongan yang berpendapatan rendah dan sederhana.

Di samping itu, faktor taraf perkahwinan juga antara pembolehubah dalam kajian Hine \& Mitchell (2003) dan Sultana (2005) yang mana mendapati bahawa pasangan yang berkahwin berpotensi tinggi dalam menggunakan kenderaan persendirian. Kajian Sungyop Kim (2009) pula menunjukkan kebanyakan imigran bujang yang berada di Amerika Syarikat kurang daripada setahun akan menggunakan pengangkutan tidak bermotor seperti basikal dan berjalan kaki untuk ke tempat kerja. Status pekerjaan turut mempengaruhi penggunaan mod pengangkutan di mana Sulzana (2010) mendapati faktor jarak ke tempat kerja yang jauh menyebabkan pengguna lebih selesa menggunakan kenderaan persendirian. Kajian Harifah et al. (2015) pengangkutan awam digunakan kebanyakannya oleh pengguna yang remaja, tidak bekerja (pelajar atau surirumah) atau yang bekerja separuh masa, berpendapatan RM800 ke bawah dan masih bujang. Hal ini berkait secara langsung dengan kestabilan sumber kewangan dan tanggungan keluarga dalam kehidupan sosioekonomi mereka.

Pemilikan kenderaan persendirian juga merupakan pembolehubah yang mempengaruhi penggunaan mod pengangkutan yang mana kan menpengaruhi kadar penggunaan pengangkutan awam. Pelbagai faktor terlibat secara langsung dengan pembolehubah pemilikan kenderaan ini. Misalnya, dalam kajian Ritter dan Vance (2013) berkenaan perkaitan populasi terhadap jumlah pemilikan kenderaan dan mendapati pertambahan penduduk memberi kesan positif terhadap pertambahan pemilikan kenderaan, namun penurunan jumlah penduduk tidak memastikan penurunan jumlah kenderaan kerana kenaikan berterusan pendapatan isi rumah. Faktor sosio demografi juga mempengaruhi pemilikan kenderaan sepertimana penemuan oleh Liu et al. (2009) menunjukkan komposisi isi rumah, lesen memandu, jarak perjalanan ke tempat kerja mempunyai kesan positif terhadap pemilikan kenderaan. Michael et al. 
(2011) mendapati walaupun pendapatan adalah pemboleh ubah utama dalam pemilikan kenderaan, namun pengguna akan beralih kepada pengangkutan awam sekiranya masa perjalanan yang diambil ke destinasi adalah sama atau lebih singkat daripada penggunaan kenderaan persendirian.

Rajah 1: Pembolehuabah Faktor Sosioekonomi yang Mempengaruhi Penggunaan Mod Pengangkutan

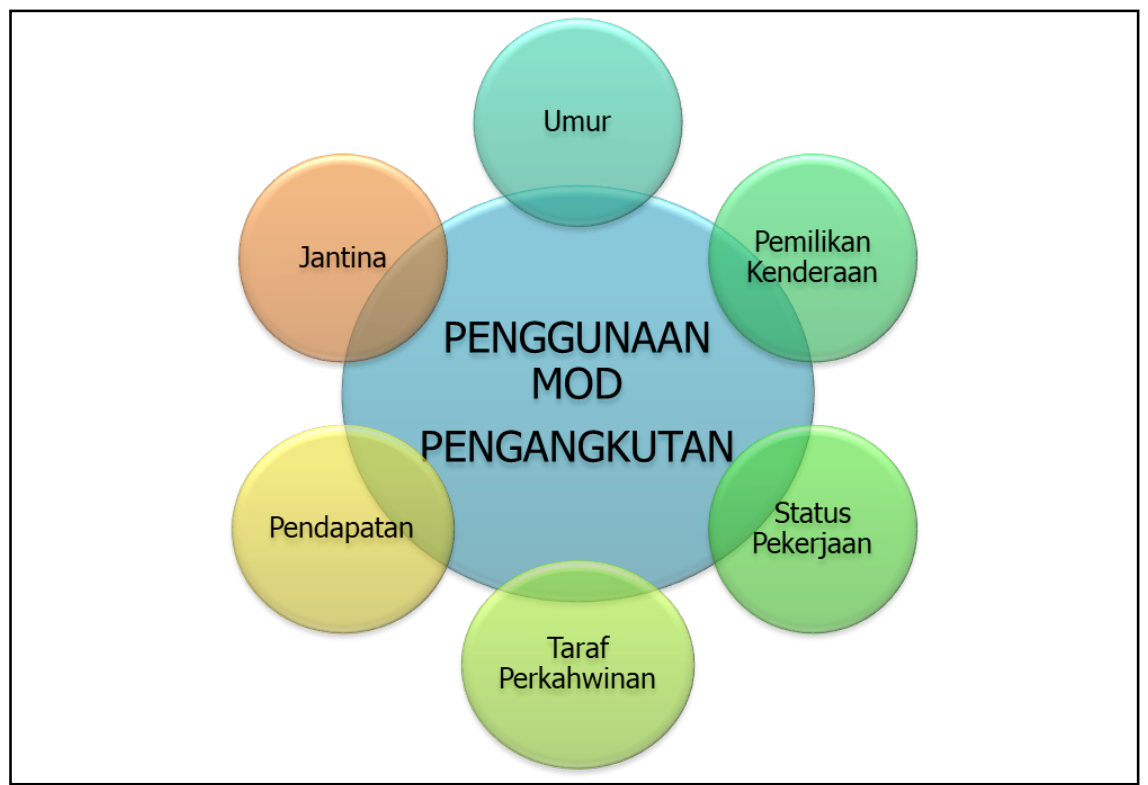

Sumber: Ubahsuai dari Hensher (1987) dan Harifah et al. (2015)

\section{Metodologi Kajian}

Kajian ini dijalankan di ibu negeri Sabah iaitu Kota Kinabalu yang mempunyai keluasan kawasan 352.10-kilometer persegi dan terletak pada kedudukan longitud geografi iaitu $116^{\circ} 2^{\prime} 0^{\prime \prime}-116^{\circ} 15^{\prime} 30^{\prime \prime}$ E dan latitude $5^{\circ} 52^{\prime} 30^{\prime \prime}-6^{\circ} 4^{\prime} 30^{\prime \prime} \mathrm{N}$.

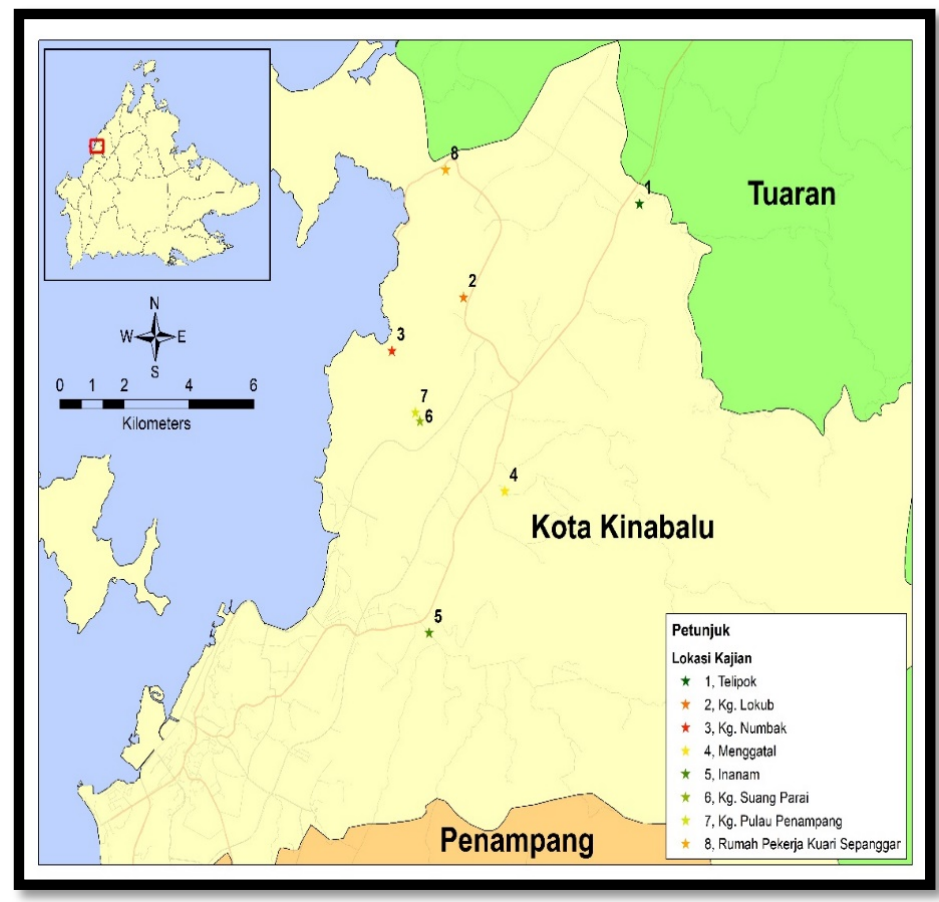

Rajah 2: Lokasi Kajian 
Kota Kinabalu merupakan pintu masuk negeri Sabah yang disempadani oleh daerah Penampang, Putatan dan Tuaran. Kota Kinabalu juga menjadi pintu masuk utama ke Kepulauan Borneo dan merupakan tumpuan segala aktiviti seperti perdagangan, perindustrian, penempatan, pengangkutan dan pelancongan (Harifah et al., 2015). Oleh itu, Kota Kinabalu adalah sesuai sebagai lokasi kajian penyelidik kerana menjadi tumpuan masyarakat tempatan mahupun asing untuk menjalankan pelbagai aktiviti sosial harian dan ia merupakan satu kawasan yang membangun dengan pesat sebagai One Stop Centre City yang mempunyai pelbagai fungsi (Saravanan et al., 2020).

Teknik pengumpulan data untuk kajian ini adalah berasaskan sumber primer dan sekunder. Sumber primer yang digunakan adalah pemerhatian secara langsung di kawasan hot spot penempatan warga asing dan perhentian bas yang berdekatan kawasan penempatan golongan ini (Rajah 2). Pemerhatian langsung ini dilakukan adalah untuk mendapatkan gambaran dan meneliti penggunaan mod pengangkutan warga asing ini untuk meningkatkan darjah ketersampaian mereka ke sesuatu tempat tertentu. Borang soal selidik turut digunakan dalam kajian ini. Pemilihan responden adalah secara bertujuan dan snow ball kepada 150 orang warga asing yang berada di sekitar Kota Kinabalu. Pemprosesan dan analisis data dengan menggunakan Statistical Package for the Social Sciences (SPSS) versi 26 dan analisis statistik deskriptif digunakan untuk menganalisis data demografi responden bagi mengambarkan taburan frekuensi dan peratusan responden serta kaedah analisis menggunakan ujian Khi-Kuasa Dua untuk menguji hubungan antara elemen-elemen sosioekonomi responden dengan penggunaan mod pengangkutan responden.

\section{Hasil Kajian dan Perbincangan Kajian}

\section{Ciri-ciri demografi responden}

Jadual 1 menunjukkan statistik demografi responden. Taburan jantina responden masing-masing adalah 50 peratus bagi lelaki dan perempuan. Majoriti responden berumur 21 hingga 30 tahun sebanyak 28.7 peratus manakala minoriti adalah responden bawah 20 tahun dengan 12 peratus. Majoriti responden juga berasal daripada Filipina dengan 76.7 peratus manakala yang lain adalah berasal dari Indonesia (17.3\%), Pakistan (3.3\%) dan India (2.7\%). Kebanyakan responden telah menetap di Sabah selama 11 ke 20 tahun sebanyak 30 peratus dan nilai peratusan yang paling rendah ialah 0.7 peratus iaitu responden yang kurang daripada setahun. Majoriti responden telah berkahwin dengan nilai peratusan 68 peratus. Kebanyakan responden masuk ke Malaysia khususnya Sabah menggunakan dokumen pasport sebanyak 36 peratus dan terdapat 15.3 peratus responden yang tidak mempunyai dokumen perjalanan yang sah. Majoriti responden bekerja sepenuh masa sebanyak 59.3 peratus diikuti oleh bekerja separuh masa sebanyak 26 peratus dan golongan tidak bekerja sebanyak 14.7 peratus. Sektor pekerjaan yang diceburi oleh responden paling tinggi adalah sektor perkhidmatan (28\%), pembinaan $(22.7 \%)$, perniagaan $(22 \%)$, perkilangan $(6 \%)$, perikanan $(4 \%)$ dan paling rendah ialah perladangan (2.7\%) serta terdapat 26.7 peratus responden yang tidak bekerja. Kebanyakan responden berpendapatan bulanan isi rumah adalah kurang daripada RM1500 sebanyak 79.3 peratus manakala responden berpendapatan bulanan yang paling tinggi adalah lebih daripada RM2501 sebanyak 4.7 peratus. Ini menunjukkan taraf hidup responden dalam kajian ini terdiri daripada kategori sederhana dan rendah.

Jadual 1: Statistik Demografi Responden

\begin{tabular}{lll}
\hline Bil & \multicolumn{1}{c}{ Item } & \multicolumn{1}{c}{ Statistik } \\
\hline 1. & Jantina & Lelaki (50\%), Perempuan $(50 \%)$ \\
2. Umur & $\begin{array}{l}\text { Bawah 20 tahun }(12 \%), 21-30 \text { tahun }(28.7 \%), 31-40 \text { tahun } \\
(26 \%), 41-50 \text { tahun }(18.6 \%), 51 \text { tahun ke atas }(14.7 \%)\end{array}$ \\
3. Negara Asal & $\begin{array}{l}\text { Filipina }(76.7 \%), \text { Indonesia (17.3\%), Pakistan }(3.3 \%), \text { India } \\
(2.7 \%)\end{array}$ \\
\hline
\end{tabular}


Tempoh masa
menetap di Sabah

5. Taraf Perkahwinan

6. Jenis Dokumen

7. Status Pekerjaan

8. Sektor Pekerjaan

9. Pendapatan Isi
Rumah
Kurang 1 tahun $(0.7 \%), 1-10$ tahun $(22.7 \%), 11-20$ tahun (30\%), $21-30$ tahun (22.6\%), $31-40$ tahun (14.5\%), $41-50$ tahun $(8.1 \%), 51$ tahun ke atas (1.4\%)

Bujang (25.3\%), Berkahwin (68\%), Duda/Janda (6.7\%)

Passport (36\%), Permit Pekerja (14.7\%), Pas Sempadan (0.7\%), Sijil Lahir (4\%), IMM13 (10.7\%), JKM (3.3\%), Penduduk Sementara (2\%), Pemastautin Tetap (13.3\%), Tiada Dokumen $(15.3 \%)$

Bekerja sepenuh masa (59.3\%), Bekerja separuh masa (26\%), Tidak bekerja (14.7\%)

Perkhidmatan (28\%), Perkilangan (6\%), Perikanan (4\%), Perladangan (2.7\%), Pembinaan (22.7\%), Perniagaan (22\%), Tidak Bekerja (14.7\%)

$<$ RM500 (11.3\%), RM501-RM1000 (46.7\%), RM1001-

RM1500 (21.3\%), RM1501-RM2000 (10\%), RM2001RM2500 (6\%), >RM2501 (4.7\%)

\section{Pengaruh Sosioekonomi terhadap Penggunaan Mod Pengangkutan}

\section{Umur}

Rajah 3 menunjukkan terdapat tidak ada perbezaan yang signifikan di antara umur dan mod pengangkutan yang digunakan $(\chi 2=14.723, \mathrm{df}=18, \mathrm{k}>0.05)$. Walaupun faktor ini tidak terdapat perbezaan yang signifikan, namun frekuensi menunjukkan pengangkutan awam dan tidak bermotor banyak digunakan oleh responden yang berumur 24 sehingga 34 tahun.

Rajah 3: Pengaruh Faktor Umur Terhadap Penggunaan Mod Pengangkutan

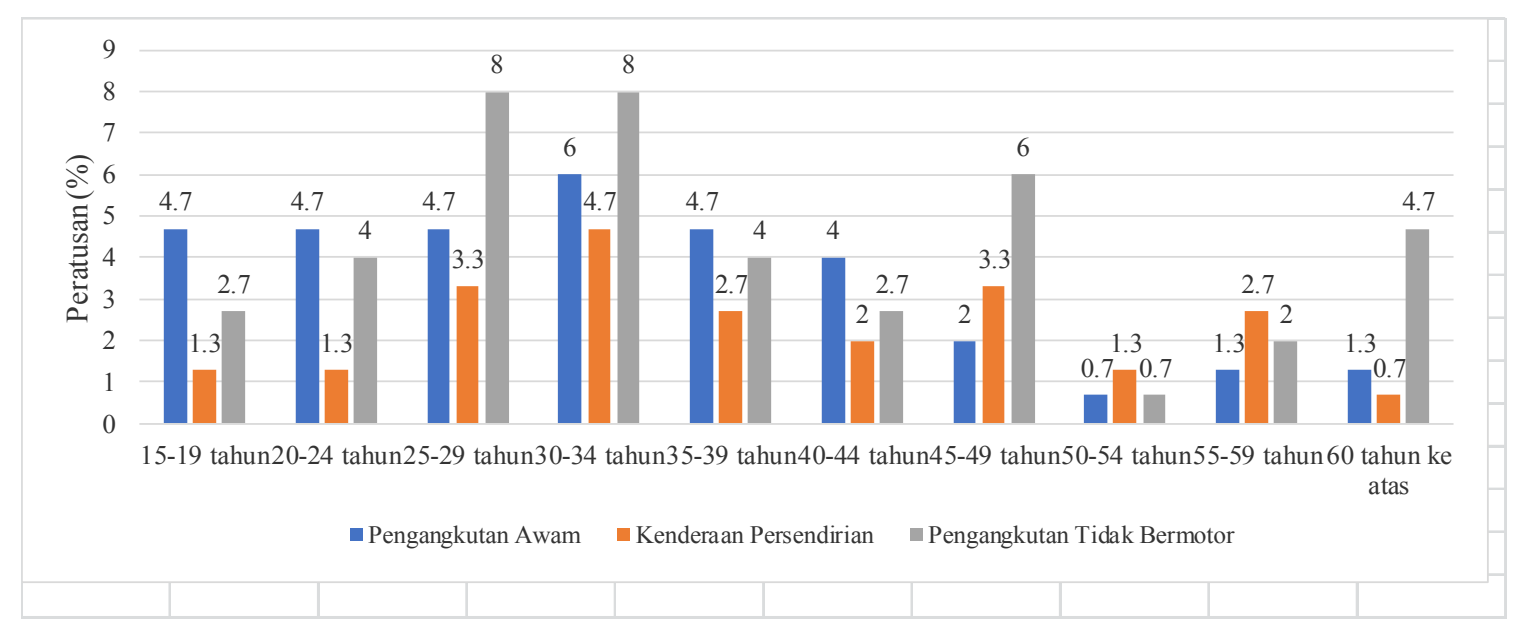

Penggunaan kenderaan persendirian pula menunjukkan pada kadar sederhana pada setiap golongan umur. Hal ini demikian kerana pendominasian penggunaan kenderaan tidak bermotor lebih tinggi pada hampir setiap golongan umur. Kenderaan tidak bermotor adalah seperti berjalan kaki dan basikal. Kebergantungan responden lebih terarah kepada pengangkutan awam dan hanya berjalan kaki untuk melakukan aktiviti harian. Perkara ini juga menunjukkan bahawa tempat kerja responden kebanyakkanya adalah berdekatan dengan kawasan penempatan mereka yang membolehkan mereka 
menggunakan mod berjalan kaki sahaja. Kecenderungan golongan muda kepada penggunaan pengangkutan awam selari dengan pendapat Driscoll et al. (2017). Manakala corak penggunaan golongan warga asing yang lebih berumur iaitu 60 tahun ke atas lebih terarah kepada pengangkutan alternatif seperti pengangkutan awam dan berjalan kaki sama sebagaimana penemuan kajian Beckman dan Goulias (2008) di California.

\section{Jantina}

Rajah 4 pula menunjukkan terdapat perbezaan yang signifikan antara jantina dan penggunaan mod pengangkutan $(\chi 2=24.903, \mathrm{df}=2, \mathrm{k}<0.05)$. Pengangkutan awam lebih banyak digunakan oleh kaum perempuan dengan 30 peratus berbanding kaum lelaki 22 peratus. Begitu juga dengan pengangkutan tidak bermotor yang majoriti digunakan oleh kaum perempuan dengan nilai yang tidak jauh berbeza iaitu 13.3 peratus dan 11.3 peratus.

Rajah 4: Pengaruh Faktor Jantina Terhadap Penggunaan Mod Pengangkutan

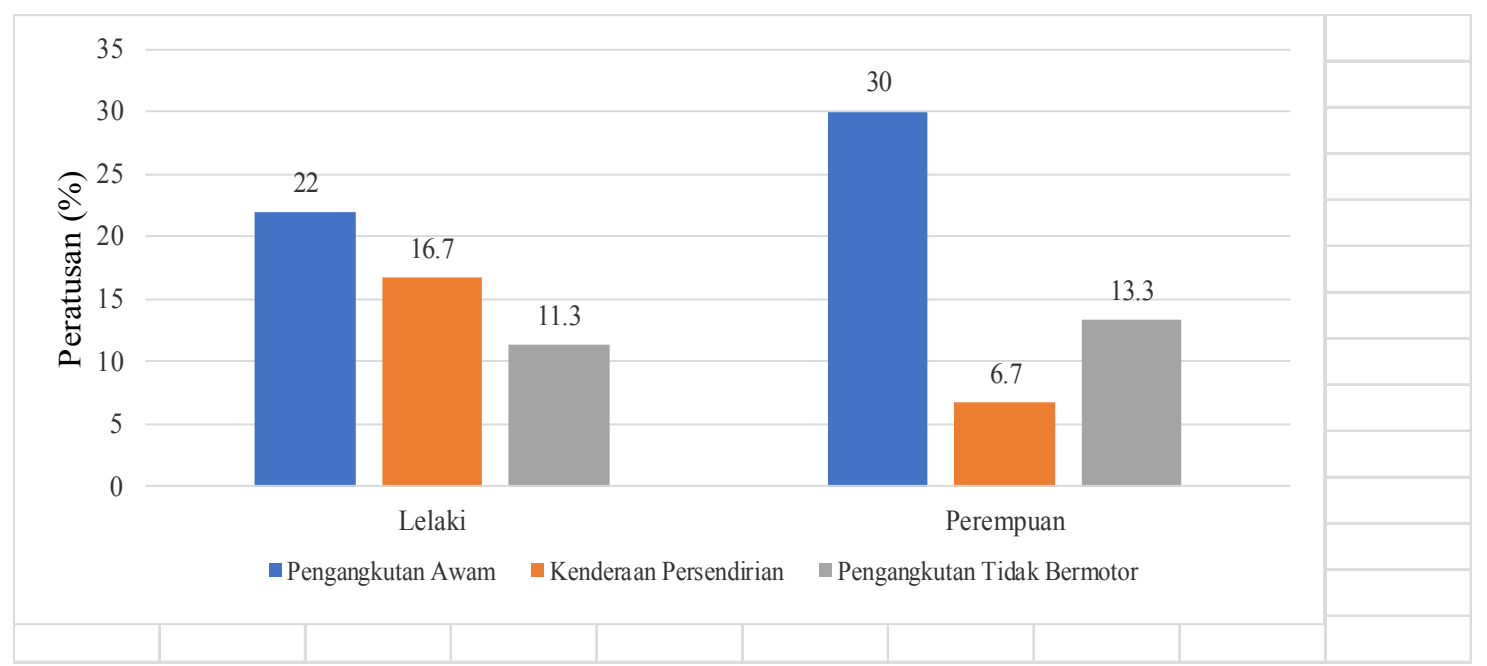

Namun begitu, kenderaan persendirian lebih dominasi oleh kaum lelaki dengan 16.7 peratus. Hal ini secara tidak langsung berkaitan dengan pemilikan lesen kenderaan yang banyak dimiliki oleh kaum lelaki berbanding kaum perempuan sepertimana kajian Heisz dan Schellenberg (2004) di Toronto yang mana golongan warga asing perempuan lebih banyak melakukan perjalanan berbanding golongan warga asing lelaki menggunakan pengangkutan awam. Kebanyakan kajian sarjana terdahulu juga menunjukkan golongan perempuan lebih banyak melakukan perjalanan yang kerap dalam lingkungan jarak yang pendek berbanding lelaki yang mana tidak berkaitan dengan pekerjaan seperti membeli barang dapur, membeli belah dan penjagaan anak (Law, 1999; Blumenberg, 2003; Khosla, 2005).

\section{Status Pekerjaan}

Ujian Khi Kuasa Dua menunjukkan terdapat perbezaan yang signifikan antara status pekerjaan terhadap mod pengangkutan responden $(\chi 2=41.671, \mathrm{df}=4, \mathrm{k}<0.05)$. Majoriti responden yang bekerja sepenuh masa menggunakan pengangkutan awam untuk bergerak ke tempat kerja dengan 28 peratus diikuti oleh pengangkutan tidak bermotor dengan 16.7 peratus dan kenderaan persendirian dengan 14.7 peratus.

Berlainan pula dengan responden yang bekerja separuh masa yang kebanyakannya lebih memilih untuk berjalan kaki sahaja ke tempat kerja dengan 11.3 peratus. Golongan responden yang tidak bekerja juga mempunyai peratusan yang tinggi bagi penggunaan pengangkutan tidak bermotor untuk bergerak ke sesuatu tempat. Penemuan ini menunjukkan corak penggunaan responden agak berbeza dengan warga tempatan yang mana golongan warga asing kebanyakan menggunakan pengangkutan awam walaupun mempunyai pekerjaan yang tetap yang mana dalam kajian Harifah et al. (2015) berkenaan corak 
penggunaan kenderaan penduduk tempatan yang bekerja sepenuh masa di Kota Kinabalu lebih terarah kepada kenderaan persendirian.

Rajah 5: Pengaruh Faktor Status Pekerjaan Terhadap Penggunaan Mod Pengangkutan

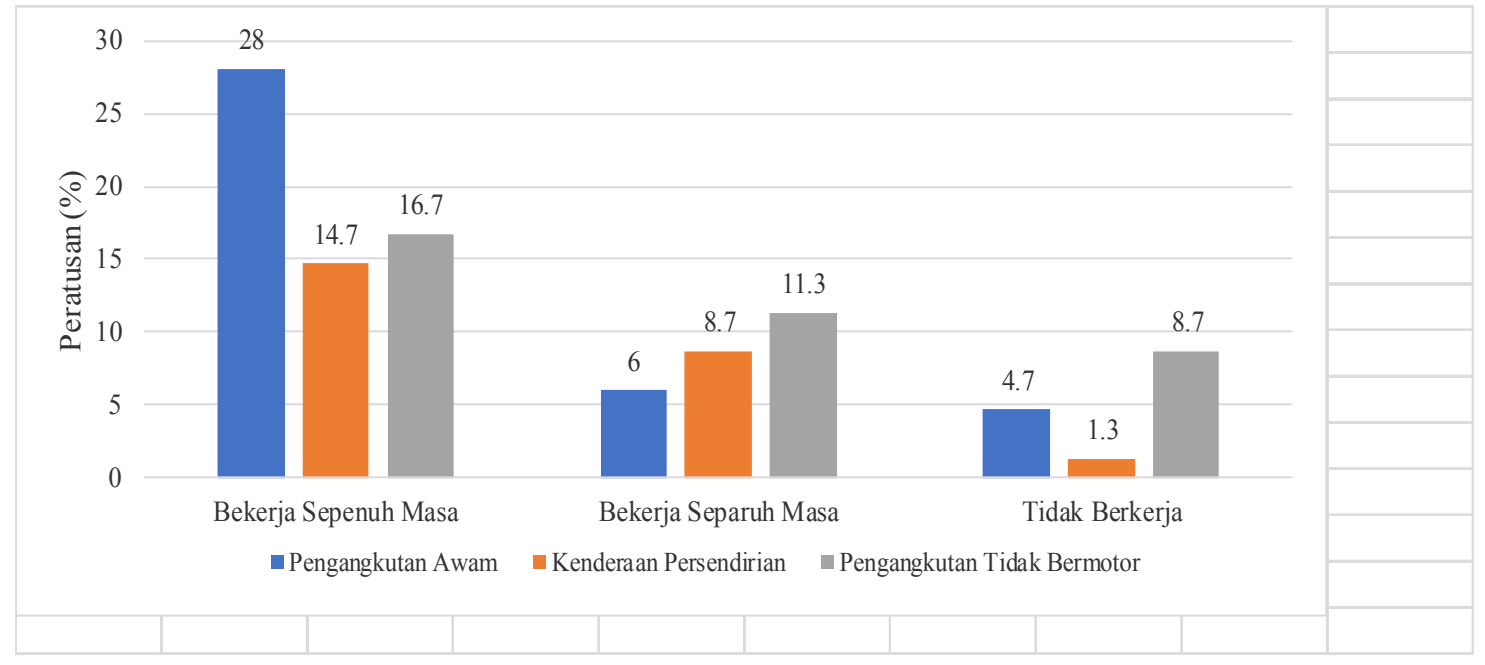

\section{Pendapatan}

Keputusan ujian Khi Kuasa Dua $\left(\chi^{2}=33.184\right.$, df $\left.=10, \mathrm{k}<0.05\right)$ menunjukkan bahawa terdapat perkaitan penggunaan mod pengangkutan yang signifikan dengan pendapatan responden. Penggunaan pengangkutan awam yang paling tinggi adalah responden yang berpendapatan RM500-RM1000 sebulan dan RM1501-RM2500. Manakala penggunaan kenderaan persendirian adalah daripada golongan yang berpendapatan tinggi iaitu RM2500 ke atas dengan 14.3 peratus berbanding mod pengangkutan yang lain.

Rajah 6: Pengaruh Faktor Pendapatan Terhadap Penggunaan Mod Pengangkutan

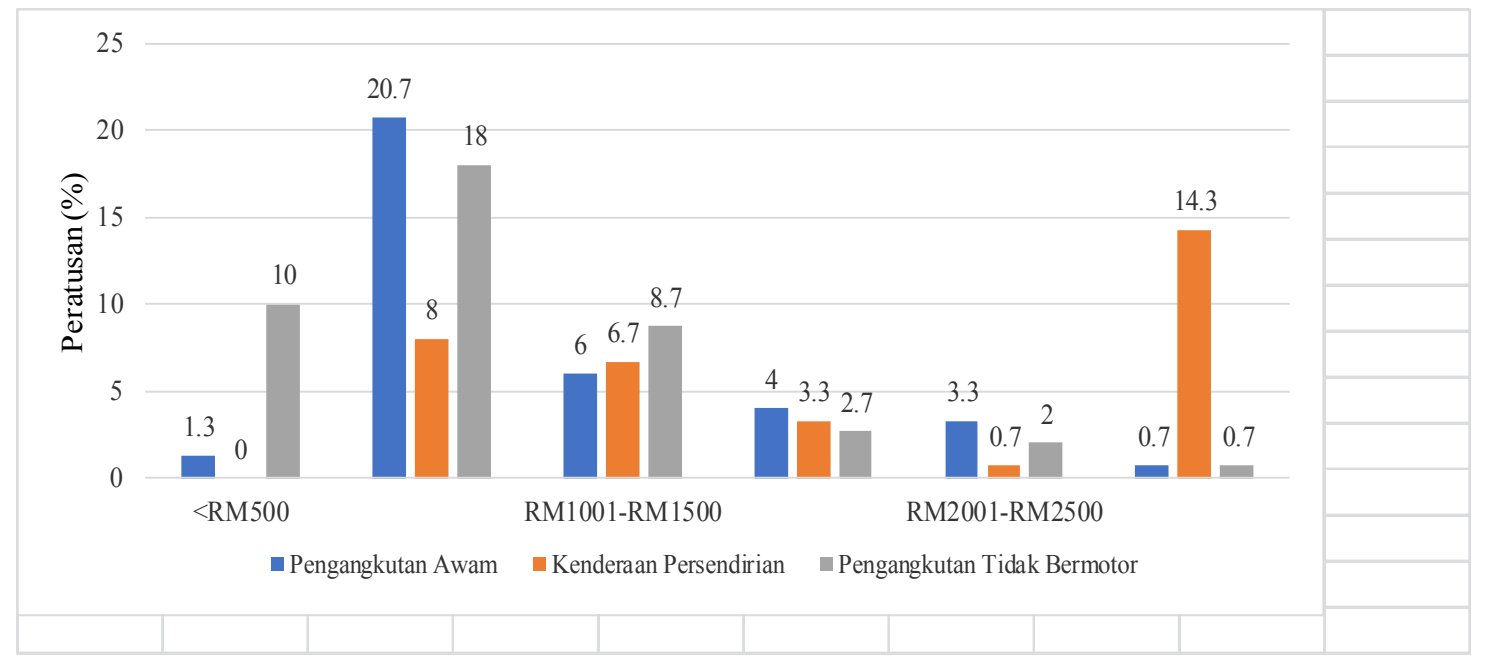

Namun begitu, berdasarkan Rajah 6 menunjukkan kadar pengggunaan kenderaan tidak bermotor juga agak tinggi daripada golongan berpendapatan rendah dan sederhana. Menurut Nizam dan Nor et al. (2011), kadar permotoran meningkat selari dengan pendapatan isi rumah. Kecenderungan responden menunjukkan lebih terarah kepada pengangkutan awam dan pengangkutan tidak bermotor pada peringkat pendapatan rendah dan sederhana dan apabila pendapatan mulai meningkat responden juga akan beralih kepada kenderaan persendirian. Perkara ini selari dengan laporan dari Jabatan Pembangunan Negeri Sabah (1999) dengan pengiraan sesebuah isi rumah mampu memiliki sekurangkurangnya sebuah kenderaan apabila gaji mereka mencapai tahap minimum RM2,500 sebulan. Pendapatan jelas merupakan faktor penting untuk warga asing terutama yang baru berhijrah yang rata- 
rata mempunyai pendapatan yang rendah. Menurut Susan Handy et al. (2008) golongan warga asing yang berpendapatan rendah ini akan kebanyakan tinggal di kawasan bandar yang mempunyai akses pengangkutan awam yang lebih baik bagi menggurangkan keperluan untuk menggunakan kenderaan persendirian.

\section{Taraf Perkahwinan}

Rajah 7 menunjukkan tidak terdapat perkaitan yang signifikan antara taraf perkahwinan dan pemilihan mod pengangkutan $\left(\chi^{2}=1.725, \mathrm{df}=4, \mathrm{k}>0.05\right)$. Namun begitu, frekuensi menunjukkan responden yang telah berkahwin dan mempunyai keluarga lebih kerap menggunakan kenderaan persendirian dengan 26.7 peratus diikuti dengan jarak peratusan yang agak jauh iaitu golongan bujang dengan 5.3 peratus dan lain-lain dengan hanya 2 peratus. Pengangkutan awam turut digunakan oleh kebanyakan responden yang berkahwin dengan 21.3 peratus. Walaupun begitu, majoriti golongan bujang menggunakan pengangkutan awam dengan mencatatkan 10.7 peratus manakala pengangkutan lain dengan 5.3 peratus dan 9.3 peratus. Penemuan ini menunjukkan golongan sasaran yang menggunakan pengangkutan awam adalah golongan bujang dan pasangan yang berkahwin pula berpontensi untuk menggunakan kenderaan persendirian. Penemuan ini juga sependapat dengan kajian Potoglou dan Kanaroglou (2008) dan Harifah et al. (2015) dimana taraf perkahwinan akan membentuk sebuah keluarga dengan pertambahan isi rumah dari semasa ke semasa dan mereka lebih memerlukan kenderaan persendirian untuk melakukan perjalanan.

\section{Rajah 7: Pengaruh Faktor Taraf Perkahwinan Terhadap Penggunaan Mod Pengangkutan}

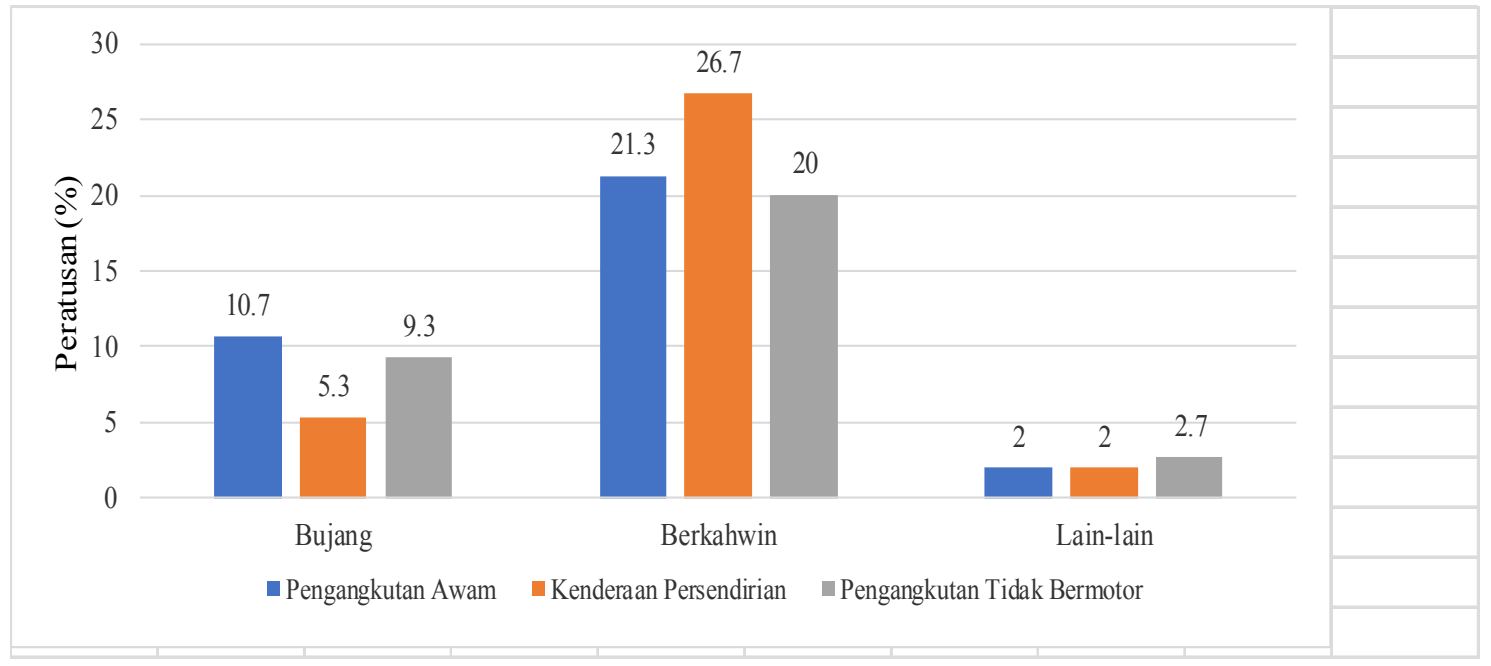

\section{Pemilikan Kenderaan}

Keputusan ujian Khi Kuasa Dua $(\chi 2=27.858$, df $=2, \mathrm{k}<0.05)$ menunjukkan bahawa terdapat perkaitan pemilihan mod pengangkutan yang signifikan terhadap pemilikan kenderaan. Responden yang tidak mempunyai kenderaan adalah cenderung untuk menggunakan penangkutan tidak bermotor dengan nilai peratusan 34 peratus dan pengangkutan awam dengan 21.3 peratus.

Sebaliknya, penggunaan kenderaan persendirian mencatatkan nilai peratusan yang paling tinggi iaitu 28.7 peratus bagi responden yang memiliki kenderaan persendirian untuk melakukan sesuatu perjalanan ke destinasi tertentu. Penemuan ini selari dengan kajian Harifah et al. (2015) di Kota Kinabalu yang mana sebahagian besar responden menggunakan kenderaan persendirian jika mempunyai kenderaan sendiri. Perkara ini jelas menunjukkan pemilikan kenderaan sememangnya mempengaruhi penggunaan mod pengangkutan walaupun golongan warga asing mempunyai trend pemilikan kenderaan yang lebih rendah berbanding warga tempatan. Warga asing akan terus berasimilasi dengan penggunaan kenderaan. Mobiliti yang semakin meningkat di peringkat antarabangsa akan mempengaruhi corak perjalanan warga asing yang hari ini lebih banyak bergantung pada kenderaan berbanding dahulu (Blumenberg dan Evans, 2007). Kajian Blumenberg (2009) 
menyatakan warga asing di Amerika Syarikat semakin bergantung kepada pemanduan kenderaan persendirian selari dengan perkembangan semasa.

Rajah 8: Pengaruh Faktor Pemilikan KenderaanTerhadap Penggunaan Mod Pengangkutan

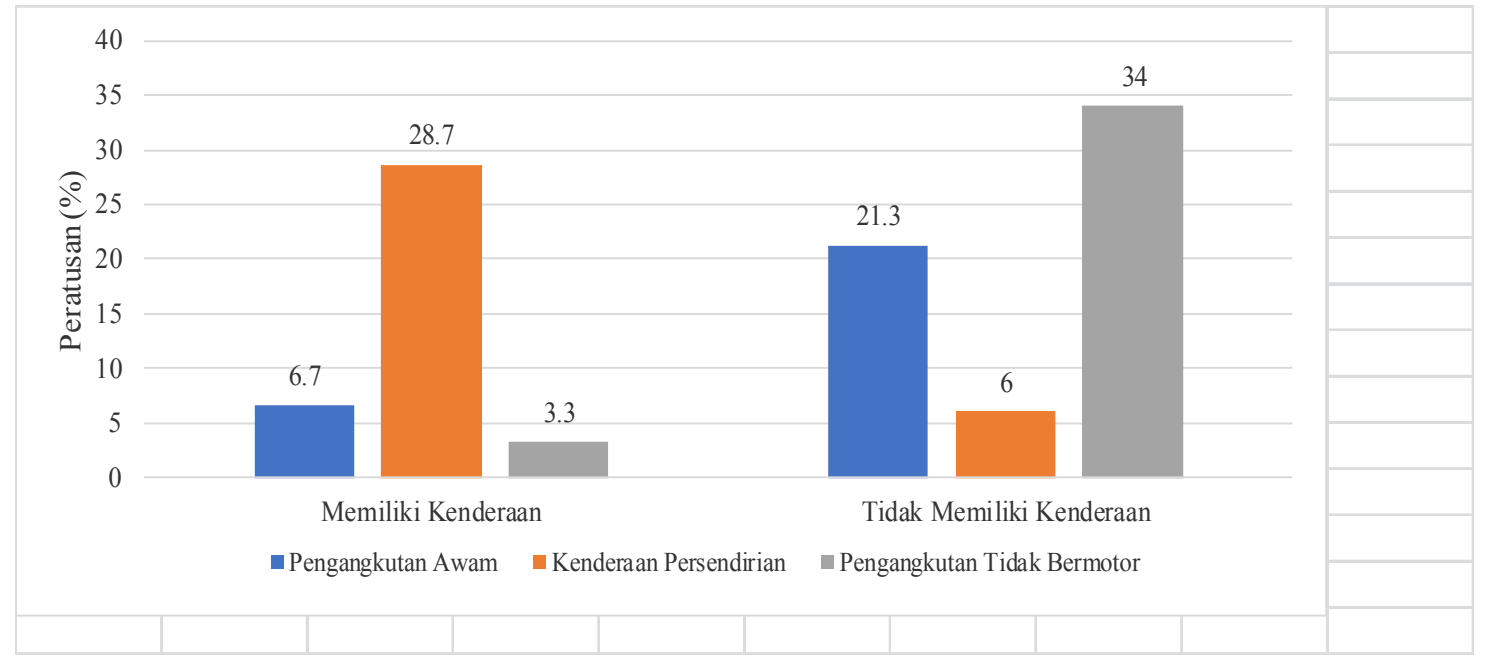

\section{Kesimpulan}

Penggunaan mod pengangkutan sememangnya dipengaruhi oleh pelbagai faktor seperti faktor sosioekomoni. Hasil ujian mendapati wujudnya pembolehubah berdasarkan latar belakang sosioekomoni seseorang individu dalam pemilihan penggunaan mod pengangkutan warga asing. Warga asing yang menggunakan pengangkutan awam terdiri daripada individu bujang yang berpendapatan rendah dan sederhana serta tidak memiliki kenderaan persendirian. Manakala pengangkutan tidak bermotor digunakan oleh individu yang tidak bekerja khususnya golongan yang berumur pertengahan dan lebih berusia yang tidak memiliki kenderaan persendirian tidak kira masih bujang ataupun sudah berkahwin. Sebaliknya kenderaan persendirian lebih banyak digunakan oleh warga asing yang berpendapatan tinggi dan satbil, berkahwin dan bekerja sepenuh masa. Corak mod pengangkutan warga asing berbeza sedikit dengan penduduk tempatan yang mana warga asing lebih cenderung untuk menggunakan pengangkutan awam dan pengangkutan tidak bermotor seperti berjalan kaki.

Namun begitu, jika kewangan warga asing berada pada tahap yang stabil mereka turut berpotensi untuk menggunakna kenderaan persendirian. Akhirnya, kesan imigrasi terhadap pengguna pengangkutan awam tetap juga tidak menentu, perkara ini sangat bergantung kepada aliran imigrasi masa depan dan juga kadar asimilasi warga asing dengan pemilikan kenderaan. Warga asing ini sememangnya tidak dinafikan merupakan salah satu golongan pengguna pengangkutan awam yang penting dalam meningkatkan tahap penggunaan pengangkutan awam khususnya di Kota Kinabalu. Oleh itu, perkhidmatan pengangkutan awam haruslah lebih berkesan agar boleh meningkatkan lagi peratusan penggunaan pengangkutan awam bagi mengurangkan penggunaan kenderaan persendirian dalam mencapai pengangkutan mapan sekaligus meningkatkan kualiti kehidupan penduduk.

\section{Penghargaan}

Penyelidik mengucapkan Terima Kasih kepada pihak Universiti Malaysia Sabah (UMS) untuk menanggung pengajian penyelidik melalui Skim Pembantu Pengajar Pascasiswazah UMS (SPP). 


\section{Rujukan}

Abd Rahim. (2004). Transport for the Under-Served in Malaysia: The Roles of Minibuses in Malaysia Town and Cities. Bangi: Universiti Kebangsaan Malaysia.

Abreha, D. A. (2007). Analyzing public transport performance using efficiency measures and spatial analysis: The case of Addis Ababa. Tesis Sarjana (Tidak diterbitkan). International Institute for Geo-Information Science and Earth Observation Enschede, Netherlands.

Balcombe R., Mackett R., Paulley N., Presto J., Sgires J., Titheridge H., dan White P. (2004). The Demand for Public Transport: A Practical Guide. TRL Report TRL 593.

Beckman, J. and Goulias, K. G. (2008). Immigration, Residential Location, Car Ownership, and Commuting Behavior: A Multivariate Latent Class Analysis from California. Transportation, 35, $655-671$.

Blumenberg, E. (2004). En-gendering effective planning: Spatial mismatch, low-income women, and transportation policy. Journal of the American Planning Association, 70(3), 269-281.

Blumenberg, E. (2009). Moving in and Moving Around: Immigrants, Travel Behavior, and Implications for Transport Policy. University of California Transportation Center UCTC Research Paper No. 892.

DBKK. (2011). Pelan Strategik Dewan Bandaraya Kota Kinabalu 2011-2015. Kota Kinabalu: Dewan Bandaraya Kota Kinabalu.

Carr, J. (1986). Passenger transport: Planning for radical change. USA: Gower Publishing.

Driscoll R. A, K. R. Lehmann, S. Polzin and J. Godfrey. (2017). The Effect of Demographic Changes on Transit Ridership Trends. TRB Working Paper, University of South Florida.

Harifah Mohd Noor, Mohd Fuad Mat Jali dan Mokhtar Jaafar. (2015). Nota Penyelidikan Pengaruh sosio-ekonomi terhadap pemilikan kenderaan di Kota Kinabalu Sabah. GEOGRAFIA Online ${ }^{\mathrm{TM}}$ Malaysian Journal of Society and Space, 11(1), 158 - 171.

Harifah Mohd Noor, Na'asah Nasrudin dan Mazdi Marzuki. (2015). Pengaruh Sosioekonomi Terhadap Penggunaan Mod Pengangkutan Awam: Kajian Bandaraya Kota Kinabalu, Sabah. Dalam. Mohmadisa Hashim et al. Persidangan Kebangsaan Geogragi dan Alam Sekitar Kali ke-5 Pemangkin Transformasi Negara. Perak: Penerbit UPSI.

Heisz, A., dan Schellenberg, G. (2004). Public Transit Use amongst Immigrants. Canadian Journal in Urban Research, 17(1), 170-191.

Hensher, D. A. 1987. Productive Efficiency and Ownership of Urban Bus Services. Transportation, 14(3): 209-225.

Hine Julian and Fiona Mitchell. (2003). Transport Disadvantage and Social Exclusion: Exclusionary Mechanisms in Transport in Urban Scotland, Aldershot: Ashgate. Journal of Social Policy, 33(3), 525-526.

Jabatan Pembangunan Negeri Sabah. (1999). Public transport masterplan study for Kota Kinabalu, Sandakan and Tawau. Final Report Summary. Department of State Development, Sabah.

K. Wang and M. Woo. (2017). The relationship between transit rich neighborhoods and transit ridership: Evidence from the decentralization of poverty. Applied Geography, 86, 183-196.

Katiman Rostam. (2002). Prinsip Asas Persekitaran Manusia. Bangi: Universiti Kebangsaan Malaysia.

Kementerian Dalam Negeri. (2018). Statistik Pekerja Asing Terkini Mengikut Negeri dan Sektor. (atas talian 16 Mac 2019) http://www.data.gov.my/data/ms_MY/dataset/statistik-pekerja-asingterkini-mengikut-negeri-dan-sektor

Khosla, P. (2005). Gendered Cities and Built Enviornments. (atas talian 16 Mac 2019) Diakses daripada The National Network on Environments and Women's Health: http://www.nnewh.org/images/upload/attach/5912gendered cities EN.pdf

Kurt R. Lehmann. (2018). Understanding the Effects of Demographic and Socio-Economic Factors on Public Transit Ridership Trends. Graduate Thesis and Dissertations. University of South Florida.

Law, R. (1999). Beyond 'women and transport': towards new geographies of gender and daily mobility. Progress in Human Geography, 23(4), 567-588.

Liu MJ et al. (2009). Analysis and modeling of private car usage through travel behavior. Journal of Jilin University, 39(2), 25-30. 
Mazdi M. dan Jamilah M. (2006). Mod Pengangkutan ke Sekolah: Satu Kajian Pilihan Pelajar-Pelajar Sekolah Menengahdi Hulu Langat. Paper presented at the Malaysian Universities Transport Research Forum Conference, Bangi.

Michael ZFLI et al. (2011). Car ownership and urban transport demand in Singapore. International Journal of Transport Economics 38(1), 47-70.

Mohammad Mustafa Ishak. (2014). Keselamatan Negara: Isu Pekerja Asing dan Cabaran Semasa. Kluster Politik, Keselamatan dan Hal Ehwal Antarabangsa. Sesi Perbincangan Meja Bulat. Putrajaya: Palm Garden Hotel.

Nizam et al. (2011). Hubungan kecederaan trafik dengan pembangunan ekonomi Malaysia. Jurnal Ekonomi Malaysia 45, 81-87.

Ritter N, V. C. (2013). Do fewer people mean fewer cars? Population decline and car ownership in Germany. Transportation Research Part A: Policy and Practice, 50, 74-85.

Saravanan Sundara Sakaran, Harifah Mohd Noor dan Rosmiza M. Z. (2020). Ketersampaian penduduk terhadap perkhidmatan pengangkutan awam di Bandaraya Kota Kinabalu, Sabah. GEOGRAFIA

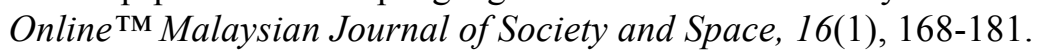

Saravanan Sundara Sakaran, Harifah Mohd Nor, Oliver Valentine Eboy. (2019). Aksesibiliti Pengangkutan Awam (Bas) Di Bandaraya Kota Kinabalu, Sabah. Jurnal Kinabalu, 25, 21-46.

Shamsudin Abdul Rahman dan Wan Rozali Wan Hussin. (2015). Perkembangan Sektor Pengangkutan Jalan Raya dan Implikasi Terhadap Struktur Bandar di Kuantan, Pahang. Dalam. Mazdi Marzuki dan Jabil Mapjabil. Isu-Isu Pengangkutan Darat di Malaysia. Johor: Penerbit UTHM.

Sultana, S. (2005). Effects of married-couple dual-earner households on metropolitan commuting: Evidence from the Atlanta metropolitan area. Urban Geography, Vol. 26(4), Hlm. 328 - 352.

Sungyop Kim. (2009). Immigrants and Transportation: An Analysis of Immigrant Workers' Work Trips. Journal of Policy Development and Research, 11, 3.

Susan Handy, Blumenberg E., Donahue M., Lovejoy K., Rodier C., Shaheen S., Shiki K. dan Song L. (2008). Travel Behavior of Mexican and Other Immigrant Groups in California. Berkeley Planning Journal, 21(1).

Taylor, B. D., \& Breiland, K. (2007). Transit's dirty little secret: The divergence of rider demographics and public policy. Paper presented at the 11th World Conference on Transport Research.

Taylor BD dan Fink CNY. (2003). The Factors Influencing Transit Ridership: A Review and Analysis of The Ridership Literature. University of California Transportation Center.

Tom Mills and Madeline Steele. (2017). In Portland, Economic Displacement May Be A Driver of Transit Ridership Loss. Transit Center. 